A RCHIWA, BIBLIOTEKI

I MUZEA KOŚCIELNE 110 (2018)

https://doi.org/10.31743/abmk.2018.110.20

KS. JÓZEF SZYMAŃSKI* - SŁUPSK

\title{
PARAFIE I DUCHOWIEŃSTWO POLSKIE W USA W WALCE O NIEPODLEGLOŚĆ POLSKI
}

Polskie parafie narodowościowe Kościoła rzymskokatolickiego w Stanach Zjednoczonych Ameryki Północnej były pierwszymi i najważniejszymi instytucjami wychodźstwa polskiego w tym kraju ${ }^{1}$. Instytucją, która w dziele unifikacji i organizacji zbiorowości polonijnej - w początkowym okresie jej rozwoju - stała się instrumentem nie mającym sobie równego². Największy rozwój i wzrost wspólnot parafialnych nastąpił w czasie wielkiej emigracji chłopskiej z ziem polskich (1870-1914)3. Pierwsza polska parafia powstała w roku 1854 w Pannie Marii w Teksasie ${ }^{4}$. W roku 1870 parafii polskich było ok. 10, w roku $1880-75$, w roku $1890-170$, w roku $1900-330$, w roku 1910 ponad 500, w roku $1920-760$, a w roku $1939-800^{5}$.

Założenie parafii ${ }^{6}$ - jak napisał Mieczysław Haiman - było najważniejszym fundamentem każdej osady polskiej, jakie zaczynały wyrastać jak grzyby po deszczu na wielkich połaciach Ameryki. Gdziekolwiek osiadła garstka Pola-

* Ks. Józef Szymański - dr hab. historii; prof. w Instytucie Historii i Politologii, Akademia Pomorskaw Słupsku; e-mail: jozef.szymanski@apsl.edu.pl

ORCID 0000-0003-3799-200X

${ }^{1}$ A. Zwiercan, Działalność Franciszkanów wśród Polonii, „Studia Polonijne”, 3 (1979), s. 125.

${ }^{2}$ B. Leś, Kościół w procesie asymilacji Polonii amerykańskiej. Przemiany funkcji polonijnych instytucji i organizacji religijnych w środowisku Polonii chicagowskiej, Wrocław 1981, s. 33.

${ }^{3} \mathrm{M}$. Czerwińska, Inkulturacyjna rola parafii polonijnej w USA na przykładzie wybranych parafii polonijnych z Chicago, Detroit i Nowego Jorku (1867-1976), „Studia Polonijne”, 28 (2007) s. 244.

${ }^{4}$ T.L. Baker, Wczesna historia osady Panna Maria w Teksasie, „Przegląd Polonijny”, 4 (1978) z. 2(8), s. 41-49.

${ }^{5}$ A. Brożek, Polonia amerykańska 1854-1939, Warszawa 1977, s. 45; Por. Historia polskich rzymsko-katolickich parafij archidiecezji filadelfijskiej $w$ Stanach Zjednoczonych Pótnocnej Ameryki, Philadelphiae 1938; L. Bójnowski, Historja parafji polskich $w$ diecezji hartfordskiej $w$ stanie Connecticut, New Britain, Conn 1939; A. Walaszek, Kościót, etniczność, demokratyzacja-parafie polonijne w USA (1854-1930), „Studia Migracyjne - Przegląd Polonijny”, 155 (2015) z. 1, s. 22.

${ }^{6}$ Cytaty z zachowaniem oryginalnego stylu, składni i ortografii. 
ków, tam przede wszystkim starano się o sprowadzenie księdza polskiego. Lud chętnie ponosił najcięższe nawet trudy, byle tylko mógł modlić się w swym własnym kościele, słyszeć polskie słowo Boże i śpiewać pieśni nabożne, przywiezione z Ojczyzny. Z przybyciem kapłana życie polskie zwykle rozrastało się szybko. Z ofiar wychodźców powstawał przede wszystkim kościółek, (...) potem szkółka parafialna. Kapłan polski stawał się nie tylko duchownym przewodnikiem, ale i nauczycielem, pośrednikiem wśród nowego otoczenia, a często wodzem całego życia parafii. Za jego zwykle radą tworzyły się towarzystwa, które uczyły lud pomagać sobie wzajemnie. On zwykle pierwszy mówił ludowi o obowiązkach względem przybranej ojczyzny i rozdmuchiwał iskrę miłości do starej ojczyzny w sercach wychodźców. Często też pomagał parafianom do zdobycia dobrobytu?

Powyższą opinię potwierdził również inny badacz dziejów Polonii w USA - Szczęsny Zahajkiewicz:

Lud nasz wyniósł z Polski wiarę ojców i ta wiara łączy go tu razem i skupia. Gdzie się tylko kilkanaście familij osiedli - myślą zaraz o wybudowaniu kościółka. Zacni kapłani zbierają zapomogi po bogatszych parafiach i zwykle w bardzo krótkim czasie wzrasta kościółek wśród kilkunastu lub kilkudziesięciu domków polskich. Lecz gdy raz zabłyśnie krzyż Zbawiciela na wieży kościelnej - byt osady jest zapewniony. Ten krzyż jest drogowskazem i przynętą dla innych. Nowe domy w około kościoła rosną jak grzyby po deszczu, ściągają nowi osadnicy, wartość gruntów idzie w górę, zakładają się różne handle - i dla biednej osady zaczyna się nowe życie, nowa era. Wraz z połyskiem krzyża - rozkwita w osadzie dobrobyt - kapłan Polak podnosi ją moralnie, zakłada polską szkołę dla dzieci a rodziców łączy w towarzystwa. Proboszcz w parafii polskiej w Ameryce jest prawdziwym ojcem duchownym swoich owieczek: ich doradcą opiekunem i faktycznym hetmanem. Wszystko co się w parafii robi, robi się za jego wiedzą i wolą i najczęściej z jego inicjatywy, prawie zawsze pod jego przewodnictwem ${ }^{8}$.

Duchowieństwo towarzysząc wychodźstwu polskiemu organizowało emigrantom życie religijne, społeczne i kulturalne. Kolonia polska tworząc wspólnotę parafialną miała świadomość, że tworzy ośrodek życia nie tylko religijnego, ale również społecznego i patriotycznego. Duchowny zaś ze względu na swoje stanowisko kapłańskie i wykształcenie, stawał się naturalnym kierownikiem i przywódcą społeczności parafialnej. Parafia pozwalała emigrantom przezwyciężyć poczucie obcości w nowym środowisku, umożliwiała nie tylko zaspokojenie potrzeb religijnych i więzi ze swoimi, kultywowanie własnych zwyczajów i tradycji w nowym środowisku, ale i kształcenie dzieci, uzyskanie pomocy charytatywnej. Przy parafiach powstawały szkoły, schroniska, świetlice dla młodzieży, przytułki i sierocińce. Sprzyjało to funkcjonowaniu bogatej sieci organizacji kulturalno-

${ }^{7}$ Cyt. za: M. Haiman, Zjednoczenie Polskie-Rzymsko Katolickie w Ameryce 1873-1948, Chicago 1948, s. 18-19; Por. F. Stasik, Polska emigracja polityczna w Stanach Zjednoczonych Ameryki 1831-1864, Warszawa 1973 s. 96; Ks. J. Szymański, Poczatki polskojęzycznej prasy katolickiej w Stanach Zjednoczonych (do roku 1890), „Scripta Historica”, 22 (2016) s. 47.

${ }^{8}$ Sz. Zahajkiewicz, Księża i parafie polskie w Stanach Zjednoczonych Pót. Am., Chicago 1897, s. 6. 
-religijnych. Z przeszczepionym na obczyźnie kultem religijnym nierozdzielnie związane było to, do czego emigranci byli przyzwyczajeni w Ojczyźnie. Duchowni w pierwszym okresie funkcjonowania parafii pełnili funkcje duszpasterza, wójta, sędziego, a często i nauczyciela ${ }^{9}$. Rola parafii znacznie więc wykraczała poza funkcje religijne. Spełniała rolę odpowiadającą na ziemiach polskich tak parafii jak i gminy ${ }^{10}$. Wielkość tworzonych parafii polskich wahała się od kilkunastu rodzin do kilkudziesięciu tysięcy wiernych - np. parafia św. Stanisława Kostki w Chicago liczyła 50.000 wiernych, Św. Trójcy w tymże mieście - 30.000 wiernych ${ }^{11}$. W 1880 r. na jednego duszpasterza przypadało ok. 2.000 wiernych, w $1910 \mathrm{r}$. - ok. 4.000. Wiele skupisk polonijnych nie miało w ogóle duszpasterza ${ }^{12}$.

Spośród duszpasterzy polskich, do pracy duszpasterskiej w Stanach Zjednoczonych przybyli m.in. z Kresów wschodnich jezuici ${ }^{13}$. Po nich swoje placówki duszpasterskie zakładali zmartwychwstańcy w roku $1866 \mathrm{w}$ Teksasie i w $1871 \mathrm{r}$. w Chicago ${ }^{14}$. Pierwszym franciszkaninem polskim na ziemi amerykańskiej był od roku 1835, o. Grzegorz Stajewicz. Później do opieki nad Polakami i Niemcami dołączyło kolejnych czterech, wśród których był o. Leopold Moczygemba, pionier polskiego duszpasterstwa w Ameryce, założyciel pierwszej parafii ${ }^{15}$. Następnie, od 1863 r. o. Józef Buczyński organizował pierwsze polskie parafie $\mathrm{w}$ stanie Wisconsin ${ }^{16}$. Istotna rolę w posłudze duszpasterskiej odgrywały także zakony żeńskie: felicjanki, benedyktynki, dominikanki i zmartwychwstanki ${ }^{17}$. $\mathrm{Z}$ życiorysów opublikowanych na początku XX w. przez ks. Wacława Kruszkę, udało się ustalić miejsce urodzenia niespełna połowy księży polonijnych. 114 z nich $(45,8 \%)$ pochodziło z zaboru pruskiego, w tym 47 z Poznańskiego, 37

9 J. Piekoszowski, Problemy Polonii amerykańskiej, Warszawa 1981, s. 67-75; M. Borys, Rola polskich parafii rzymskokatolickich $w$ życiu Polonii chicagowskiej $w$ XIX wieku, „Studia Polonijne", 30 (2009) s. 151-171; S. Piech, Wkład księży diecezji tarnowskiej w duszpasterstwo Polonii zagranicznej (1873-1914), „Tarnowskie Studia Teologiczne”, 10 (1986) s. 118-119; Czerwińska, Inkulturacyjna rola parafii polonijnej, s. 244.

${ }^{10}$ T. Radzik, Polonia amerykańska wobec Polski (1918-1939), Lublin 1986, s. 380.

${ }^{11}$ W. Kruszka, Historya polska w Ameryce. Początek, wzrost i rozwój dziejowy osad polskich w Pótnocnej Ameryce (w Stanach Zjednoczonych i Kanadzie), t. 13, Milwaukee, Wis, 1908, s. 3; Walaszek, Kościót, etniczność, demokratyzacja-parafie polonijne, s. 22.

${ }^{12} \mathrm{P}$. Taras, Problemy duszpasterstwa polonijnego na przyktadzie USA, „Studia Polonijne”, 2 (1977) s. 188.

${ }^{13}$ S. Filipowicz, Saga polskich Jezuitów w USA, Kraków 2004; S. Włoszczewski, Polonia amerykańska. Szkice historyczne i socjologiczne, Warszawa 1971, s. 40-42, 102.

${ }^{14}$ B. Micewski, Polonijna działalność Zmartwychwstańców, w: Działalność męskich zgromadzeń zakonnych wśród Polonii, red. J. Bakalarz, Lublin 1982, s. 424-442.

${ }^{15}$ Z. Gogola, Praca franciszkanów polskich wśród Polonii na przełomie XIX/XX, do 1939 roku, „Przegląd Kalwaryjski”, 13 (2009) s. 212-213.

${ }^{16}$ A.J. Szteinke, Bracia Mniejsi na rzecz Polonii w Stanach Zjednoczonych Ameryki Pótnocnej w XIX i XX wieku, „Przeglad Kalwaryjski”, 13 (2009) s. 139.

${ }^{17}$ Brożek, Polonia amerykańska 1854-1939, s. 43; D. Praszałowicz, Rola żeńskich zakonów $w$ życiu skupisk polonijnych w Stanach Zjednoczonych, w: Polska-Dwa Światy. Kraj i Polonia, red. W. Gliński, W. J. Wysocki, Warszawa 2009, s. 205-220; T. Wojewoda, Problemy szkolnictwa polonijnego w USA w świetle relacji ks. Józefa Rokosznego, „Studia Polonijne”, 21 (2000) s. 82-84. 
z Pomorza Wschodniego oraz 27 ze Śląska; z tej liczby jednak tylko 15 przyjęło święcenia kapłańskie w zaborze pruskim ${ }^{18}$.

Od 1870 r. wśród Polonii amerykańskiej ścierały się dwa kierunki starające się jednoczyć Polaków amerykańskich: jeden dążył do zintegrowania działań społeczno-politycznych wokół ośrodków kościelnych (parafii, towarzystw katolickich), drugi starał się robić to przede wszystkim w oparciu o organizacje narodowe, uważając religię za zagadnienie ściśle osobiste ${ }^{19}$. Zdaniem ks. Romana Nira - Kościół wówczas nie był zwalczany, a jedynie „separowany” od życia narodowego ${ }^{20}$. W październiku 1873 r., z inicjatywy księży polskich, głównie ks. Teodora Gieryka, powstało Zjednoczenie Polskie Rzymsko-Katolickie (dalej: ZPRK), stowarzyszenie ubezpieczeniowe skupiające wyłącznie katolików Organizacja ta opierając się na działalności Zmartwychwstańców, wychodząc poza swoją funkcję wzajemnej pomocy, propagowała wśród Rodaków w Ameryce katolicyzm i polskość ${ }^{21}$. Jak wskazywał Florian Stasik - Zmartwychwstańcy w swoim oddziaływaniu na rodaków - mieli na uwadze przede wszystkim:

zachowanie religii, obyczajów i języka polskiego, kwestii zaś walki o wyzwolenie narodowe nie uwzględniali prawie wcale. Taka ich postawa dała powód do rozpoczęcia zaciekłej walki z nimi zwolenników nurtu narodowego (...). Na płaszczyźnie więc nie tyle wierzeń religijnych, ile stosunku reprezentowanego wobec sprawy narodowej przez organizacje emigracyjne, nastąpiło swoiste rozbicie wychodźstwa polskiego ${ }^{22}$.

Zamknięta formuła Zjednoczenia, propagująca stereotyp „Polak-katolik”, doprowadziła w sierpniu 1880 r. do powołania Związku Narodowego Polskiego (dalej: ZNP), który w swoje szeregi przyjmował wszystkich Polaków, bez względu na przekonania religijne ${ }^{23}$. Odtąd walka o wpływy absorbowała siły skupione wokół stronnictwa religijno-patriotycznego (Zjednoczenie Polskie Rzymsko Katolickie) ze stronnictwem narodowo-liberalnym, opierającym się o Związek Narodowy Polski. W praktyce walka toczyła się między środowiskami kościelnymi, skupionymi w większości pod przewodnictwem Zmartwychwstańców, a grupą działaczy świeckich skupioną w parafii Św. Trójcy ${ }^{24}$.

${ }^{18} \mathrm{~K}$. Groniowski, Emigranci z zaboru pruskiego w Stanach Zjednoczonych, „Komunikaty Mazursko-Warmińskie", 3-4 (1988) s. 317.

${ }^{19}$ Haiman, Zjednoczenie Polskie-Rzymsko Katolickie w Ameryce, s. 40-41; Walaszek, Kościót, etniczność, demokratyzacja - parafie polonijne, s. 25; Leś, Kościół w procesie asymilacji Polonii amerykańskiej, s. 114.

${ }^{20}$ R. Nir, Polonijne czasopisma religijne, w: Encyklopedia Katolicka, t. 15. Lublin 2011, kol. 1138; Walaszek, Kościót, etniczność, demokratyzacja-parafie polonijne, s. 25.

${ }^{21}$ Kruszka, Historya polska w Ameryce, t. 3, s. 144-145; Haiman, Zjednoczenie Polskie-Rzymsko Katolickie w Ameryce, s. 29-34, 57.

${ }^{22}$ Stasik, Polska emigracja polityczna w Stanach Zjednoczonych, s. 95-97.

${ }^{23}$ Haiman, Zjednoczenie Polskie-Rzymsko Katolickie w Ameryce, s. 57-63.

${ }^{24}$ R. Nir, Bibliografia selektywna Dziennika Chicagoskiego 1892-1895, 1898-1899, Select Bibliography Dziennik Chicagoski 1892-1895, 1898-1899, w: Yearbook Polish American Archives, Rocznik Archiwum Polonii, Vol. II, Orchard Lake, Michigan-Częstochowa 2004, s. 367; D. Kiper, „Przyjaciel Ludu” wobec prób zjednoczenia Polonii amerykańskiej w latach 1880-1881, „Studia 
Ton podejmowanym inicjatywom $\mathrm{w}$ ramach obydwu organizacji nadawało duchowieństwo polskie. Ze Zjednoczeniem związane było założone w roku 1875 Towarzystwo Księży Rzymsko-Katolickich Polskich. Natomiast ze ZNP konkurencyjne Stowarzyszenie Księży Polskich ${ }^{25}$.

Księża Związkowi - jak zauważył Haiman - ogłosili w prasie, że przekonawszy się, iż Związek ma na celu dobro ogólne, nie ubliżające w niczem ani religji katolickiej, ani też narodowości polskiej, postanowili popierać go całą siłą dopóty, dopóki nie odstąpi od przyjętych praw tyczących się Kościoła i religji katolickiej ${ }^{26}$.

Stąd też, w 1886 r. ZNP jasno zadeklarował, iż: ,jako przedstawiciel narodu działać będzie legalnie na korzyść niepodległości ziem polskich w Europie wszelkimi godziwymi środkami”"27.

Sprawa niepodległości Polski była ideą przewodnią wielu organizacji polskich podejmujących próby zjednoczenia się w oparciu o wspólny cel ${ }^{28}$. Jedną z pierwszych działających w tym duchu organizacji, była Liga Polska, zorganizowana w r. 1894 przez grupę duchownych rzymskokatolickich i świeckich patriotów. Do Ligi mogły przystępować wszystkie polskie stowarzyszenia i parafie. Związek Narodowy Polski odmówił jednak współpracy. Podejmowane wówczas próby skonsolidowania Polonii do roku 1912 okazały się nieskuteczne ${ }^{29}$.

Różnice występujące między Związkiem i Zjednoczeniem na początku XX wieku nie miały większego znaczenia. Zjednoczenie było odłamem „katolickim” lub „klerykalnym”, a Związek - „narodowym” lub „liberalnym”. Organizacje polsko-amerykańskie, które powstawały w tym czasie, identyfikowały się zazwyczaj z jednym z tych odłamów. Historia Polonii amerykańskiej z okresu przed I wojną światową sprowadzała się głównie do rywalizacji między tymi odłamami ${ }^{30}$. Obydwa te nurty dążąc do zachowania integralności kulturowej rodaków, ze względu na cel nadrzędy - niepodległość Rzeczpospolitej - w realizację, którego były zaangażowane, cieszyły się poparciem polskich duszpasterzy. Obradujący wówczas, 7-8 lutego 1912 r. na zjeździe w Detroit kapłani polscy, w większości mając świadomość swej tożsamości - pod przewodnictwem bpa Pawła Rhode utworzyli

Polonijne”, 33 (2012) s. 82-83; Walaszek, Kościót, etniczność, demokratyzacja-parafie polonijne, s. 25.

${ }^{25}$ Haiman, Zjednoczenie Polskie-Rzymsko Katolickie w Ameryce, s. 79-84; Leś, Kościót w procesie asymilacji Polonii amerykańskiej, s. 116; Szymański, Początki polskojęzycznej prasy katolic$k i e j$, s. 50-53.

${ }^{26}$ Cyt. za: Haiman, Zjednoczenie Polskie-Rzymsko Katolickie w Ameryce, s. 79.

${ }^{27}$ Cyt. za: M. Szawleski, Wychodźstwo polskie w Stanach Zjednoczonych Ameryki, Lwów 1924, s. 112; H. Kubiak, Polożenie społeczne i ewolucja świadomości narodowej ludności polskiej w USA w latach 1900-1919, w: Polonia wobec niepodlegtości Polski w czasie I wojny światowej, red. H. Florkowska-Franćić, M. Franćić, H. Kubiak, Wrocław 1979, s. 52.

${ }^{28}$ Leś, Kościót w procesie asymilacji Polonii amerykańskiej, s. 114-115.

${ }^{29} \mathrm{~W}$. Galush, Polacy amerykańscy i nowa Polska. Przyktady przemiany orientacji etnicznej, „Przegląd Polonijny”, 6 (1980) z. 3(17), s. 89; Haiman, Zjednoczenie Polskie-Rzymsko Katolickie w Ameryce, s. 93-99; Brożek, Próby zjednoczenia Polonii amerykańskiej, s. 153.

${ }^{30}$ Galush, Polacy amerykańscy, s. 87; Szymański, Początki polskojęzycznej prasy katolickiej, s. 53 . 
Zjednoczenie Kapłanów Polskich w Ameryce. Organizacja w początkowej fazie liczyła przeszło 700 duchownych, którzy pełnili posługę duszpasterską wśród 3. milionowej ludności polskiej. Dla propagowania tej idei bp P. Rhode wywierał odpowiedni nacisk na Zjednoczenie Kapłanów Polskich w Ameryce, by ci z kolei w swoich parafiach przygotowywali wiernych do tego wydarzenia. Zjednoczenie odegrało istotną rolę w zmobilizowaniu Polonii amerykańskiej do walki o niepodległość kraju ojców ${ }^{31}$. W następstwie podejmowanych działań, w grudniu 1912 r., w przededniu I wojny światowej, przywódcy największych polskich organizacji spotkali się w Pittsburghu, ,przyrzekłszy wszelkimi środkami poprzeć ruch powstańczy przeciwko Rosji, zorganizowali się w Komitet Obrony Narodowej do walki zbrojnej za niepodległą Rzeczpospolitą Polską"32. Pod wpływem jednak perswazji Romana Dmowskiego i Ignacego Paderewskiego doszło do rozbicia KON przez Zjednoczenie i znaczną liczbę księży, którzy pod przewodnictwem bpa P. Rhodego 8 czerwca 1913 r. powołali Polską Radę Narodową w Chicago, organizując następnie 7-8 lipca 1914 r. I Zjazd nowej organizacji. Założyciele Polskiej Rady Narodowej zobowiązali się w jednogłośnie przyjętej rezolucji „nie odstępować od obowiązku współdziałania z Krajem Ojczystym we wszelkiej akcji, mającej na celu przywrócenie niepodległości politycznej Polsce"33.

W związku z wybuchem I wojny światowej, 2 października 1914 r. Rada Narodowa i Komitet Obrony Narodowej powołały Centralny Komitet Polski. Do Komitetu Wykonawczego wspomnianej organizacji, niosącej przede wszystkim pomoc charytatywną rodakom na ziemiach polskich, wchodził $\mathrm{z}$ ramienia duchowieństwa ks. Władysław Zapała. W dniu 12 października 1914 r., pod wpływem sugestii Departamentu Stanu akcentującego neutralność rządu Stanów Zjednoczonych, na zebraniu plenarnym Zjednoczenia uchwalono zmianę nazwy organizacji na Polski Centralny Komitet Ratunkowy. W swojej odezwie z dnia 1 listopada 1914 r. skierowanej do społeczeństwa amerykańskiego apelował o pomoc, przypominając tragiczną sytuację narodu polskiego ${ }^{34}$.

Po 1900 r. rozwinęły się na ziemiach polskich dwa zasadnicze nurty polityczne, z których każdy szukał poparcia wśród amerykańskich Polaków. Zarówno Roman Dmowski, jak i Józef Piłsudski dążyli do nawiązania kontaktów z Polonią amerykańską, która reprezentowała podobne poglądy polityczne i zabiegali o ich wsparcie finansowe ${ }^{35}$. Dmowski, umiarkowany konserwatysta związany z Kościołem rzymskokatolickim, apelował do obozu katolickiego. W połowie

${ }^{31}$ Haiman, Zjednoczenie Polskie-Rzymsko Katolickie w Ameryce, s. 261; W. Szulist, Kaszuba Paweł Piotr Rhode - biskup i działacz polonijny w Stanach Zjednoczonych (1870-1945), „Studia Polonijne”, 8 (1984) s. 188-190; Galush, Polacy amerykańscy, s. 89.

${ }^{32}$ Haiman, Zjednoczenie Polskie-Rzymsko Katolickie w Ameryce, s. 264.

${ }^{33}$ Tamże, s. 267.

${ }^{34}$ Haiman, Zjednoczenie Polskie-Rzymsko Katolickie w Ameryce, s. 278-279; Brożek, Próby zjednoczenia Polonii amerykańskiej, s. 157; M.M. Drozdowski, Z dziejów stosunków polsko-amerykańskich 1776-1944, Warszawa 1982, s. 88.

${ }^{35}$ M. Zgórniak, Rola Polonii w walce zbrojnej o niepodległość Polski w latach 1914-1918, w: Polonia wobec niepodlegtości Polski w czasie I wojny światowej, red. H. Florkowska-Franćić, M. Franćić, H. Kubiak, Wrocław 1979, s. 30-31. 
1913 r. założył Komitet Narodowy Polski, który później przemianowany został na Wydział Narodowy Polski. Natomiast Piłsudski i jego stronnicy szukali poparcia wśród Polaków „postępowych”, którzy byli zorganizowani w ramach Komitetu Obrony Narodowej. Gdy w sierpniu 1914 r. wybuchła wojna, Polonia amerykańska ze względu na różnicę poglądów co do sprawy niepodległości Polski podzielona była na dwa zasadnicze odłamy. Wydział Narodowy podzielał pogląd Dmowskiego, Komitet Obrony Narodowej - Piłsudskiego ${ }^{36}$.

Parafie polskie niezależnie od akcji Komitetu przekazywały spontanicznie dary i pieniądze rodakom $\mathrm{w}$ kraju, również za pośrednictwem powstałego w styczniu 1915 r., Generalnego Komitetu Pomocy Ofiarom Wojny w Polsce, kierowanego przez Henryka Sienkiewicza, Ignacego Paderewskiego i Antoniego Osuchowskiego ${ }^{37}$. Stolica Apostolska, a przede wszystkim papież Benedykt XV, poparła akcję wspomnianego Komitetu, co ułatwiło zdobycie dla sprawy ofiar wojny na ziemiach polskich prawie całego duchowieństwa polskiego w Stanach Zjednoczonych. W tych okolicznościach w maju 1915 r. przybył do Stanów Zjednoczonych Ignacy Paderewski. Wobec rozbicia Polonii amerykańskiej na dwie zasadnicze orientacje: jedną większościową popierającą politykę R. Dmowskiego, i drugą mniejszościową popierającą politykę J. Piłsudskiego, usiłował je godzić. Z czasem jednak w swoich działaniach oparł się na Polskiej Radzie Narodowej i biskupie P. Rhodem ${ }^{38}$. Zresztą - jak zauważył Marian Drozdowski - Polska Rada Narodowa, PCKR i duchowieństwo polonijne witali Paderewskiego jako swego ideowego przywódcę. „Dziesiątki tysięcy ludzi gromadziły się na wiecach, na których przemawiał „mistrz fortepianu”39. Komitet Ratunkowy 17 sierpnia $1916 \mathrm{r}$. przekształcił się w Wydział Narodowy Polski z Janem Smulskim na czele ${ }^{40}$. Organizacja ta dzięki poparciu duchowieństwa i stworzeniu mocnej bazy terenowej Komitetów Obywatelskich, opartych na parafiach miała bardzo znaczące oddziaływanie wśród społeczności polonijnej ${ }^{41}$. Świadczy o tym m.in. list ks. Lucjana Bójnowskiego:

${ }^{36}$ Galush, Polacy amerykańscy, s. 91; T. Radzik, Spoleczno-ekonomiczne aspekty stosunku Polonii amerykańskiej do Polski po I wojnie światowej, Wrocław 1989, s. 10.

${ }^{37}$ Haiman, Zjednoczenie Polskie-Rzymsko Katolickie w Ameryce, s. 278-279; Drozdowski, Z dziejów stosunków polsko-amerykańskich, s. 89.

${ }^{38}$ M.M. Drozdowski, Stosunki polsko-amerykańskie w latach 1917-1919 w świetle Archiwum Politycznego Ignacego Paderewskiego, „Przegląd Polonijny”, 3 (1977) z. 1(5), s. 8; Szulist, Kaszuba Pawet Piotr Rhode - biskup i działacz polonijny w Stanach Zjednoczonych, s. 190.

${ }^{39}$ Drozdowski, $Z$ dziejów stosunków polsko-amerykańskich, s. 89.

${ }^{40}$ Brożek, Próby zjednoczenia Polonii amerykańskiej, s. 157.

${ }^{41}$ Radzik, Społeczno-ekonomiczne aspekty stosunku Polonii amerykańskiej, s. 10; tenże, Polonia amerykańska wobec Polski, s. 19. 


\section{LIST DO GENERAŁA JÓZEFA HALLERA}

New Britain, Conn.

Listopada 30-go 1923 r.

Szanowny Pan Generał Józef Haller.

Szanowny Panie Generale:

Jako założyciel i proboszcz przez 28 lat w parafji polskiej Najśw. Serca Jezusowego w New Britain, Conn. i jako były oficer rekrutacyjny polskich wojsk w Ameryce, oraz członek Obrony Krajowej Stanów Zjednoczonych w stanie Connecticut, (To znaczy: że należałem do Komisji wojennej amerykańskiej w stanie Connecticut w czasie wojny wszechświatowej, i bywałem na naradzie wojennej przynajmniej raz na tydzień u gubernatora), upraszam w imieniu swoim, ażeby Sz. Pan Generał z łaski swojej raczył choć na chwilkę wstąpić w progi moje i zobaczyć co Polacy zdziałali w New Britain dla siebie i dla Ojczyzny i Ameryki i podziękować Polakom i Amerykanom za pracę.

Gdy widziałem Sz. P. Generała w Chicago, na moją prośbę, raczył powiedzieć swojemu adjutantowi, żeby zaznaczył w programie, kiedy będzie w New Britain odwiedzać moją szkołę i sierociniec, z tej przyczyny ponawiam moją prośbę i proszę z łaski swojej oznaczyć czas i godzinę kiedy raczy wykonać swoje polecenie, abym mógł wraz z sierotami i szkołą przygotować się na przyjęcie Sz. p. generała na plebanji, sierocińcu i szkole. Przytem [...] jako były oficer rekrutacyjny zdaje swoje sprawozdanie pisemnie przed swoim generałem, ażeby wiedział co my uczyniliśmy, i że komitet podróży Sz. p. generała nie powinien nas lekceważyć i nie przeszkadzać na dłuższy pobyt w New Britain.

My pierwsi w całej Ameryce przed wojną wszechświatową zawiązaliśmy w New Britain Komitet Obywatelski. Dziś jeszcze posiadamy protokóły, a jeden bardzo ważny z dnia 2-go Maja 1915 r. gdzie postanowiliśmy trzymać z aljantami i posyłać pieniądze do sz. p. H. Sienkiewicza w Szwajcarji. Sz. p. H. Sienkiewiczowi w Grand Hotelu w Vevey, w Szwajcarji odesłaliśmy
d. 3 lipca $1915 \mathrm{r}$.
$3,300.00$
15-go września ,'
10.00
20-go
7-go grudnia $1917 \mathrm{r}$.
$1,746.96$
3-go czerwca $1918 \mathrm{r}$.
432.00
22-go września „,
770.00

Przed rozpoczęciem wojny zebraliśmy dolarów 1,000.00 na Oswobodzenie Ojczyzny, które w czasie wojny zostały wręczone sz. p. Paderewskiemu dnia 23go stycznia 1917 r. w Gotham Hotel New York, razem.

Kampanja od Września 1917 r. do Grudnia 1920 r.

Rada Narodowa $\quad 17,556.10$

Na sprawy polskie

Kasa Inwalidów $\quad 23,114.16$

Fundusz Kom. Ob. $\quad 1,990.97$

Przed wojną $\quad 7,260.96$

W czasie wojny $\quad 182,911.84$

Kółko Polek $33,299.87$ $7,260.96$

Polski Biały Krzyż

$8,844.36$ 


$\begin{array}{lrlr}\text { Bondy polskie } & 180,000.00 & \text { 10-Milion. Fund. } & 44,019.08 \\ \text { Podatek Narodowy } & 4,729.68 & & \\ \text { Na sprawy polskie } & 370,172.80 & \text { Sieroty w Polsce } & 44,360.90 \\ \text { Na Amer. } & 500,000.00 & \text { Am. Czerw. Krzyż } & 4,996.72 \\ \text { Razem wszystkiego } & 870,172.80 & \text { W czasie wojny raz. } & 182,911.84 \\ \text { Na polskie bondy Polacy złożyli } & \bullet & 180,000.00 \\ \text { Na Amerykańskie bondy „” ", } & 500,000.00 \\ \text { Przed wojną o wolność Polski } & & 7,260.96 \\ \text { Razem, wszystkiego przed i we wojnie } & 870,172.80\end{array}$

Do armii amerykańskiej pierwszy oddział wyjechał z New Britain dnia 5-go września 1917 r. a ostatni w październiku 1918 r. - razem poszło Polaków do armji amerykańskiej 675

Do armji polskiej pierwszy oddział wyjechał z New Britain 82 członków 29-go listopada 1917 r., a ostatni oddział 3-go lutego 1919 r. Do armji polskiej wstąpiło ochotników - razem.....290, do armji Polskiej i Amerykańskiej razem Polaków wstąpiło 965. Z New Britain zabito w polskiej i amerykańskiej armji Polaków i nie Polaków 123.

Wszystkiego z New Britain poszło do wojska.......... 3,800

co stanowi co czwarty żołnierz to Polak - a mężczyzn polskich, było wtedy w parafji 3,500, co stanowi, że co trzeci to poszedł do wojska. Że więcej nie wstąpiło do armji polskiej, wina śmietanki polskiej w New Britain, która trzymała z Niemcami, a potem brano Polaków do armji Amerykańskiej.

Na ostatnim Sejmie Wychodźtwa w Pittsburghu, sz.p. Smulski, prezes Wydziału Narodowego, zdając sprawozdanie na Sejmie publicznie przyznał nam pierwszeństwo w całej Ameryce na polu pracy i ofiar.

W styczniu 1920 r. ustąpiłem z Komitetu Obywatelskiego, usunąłem się w zacisze, $[\ldots]$

Chcę zwrócić uwagę na następne punkty naszych zasług.

1. My pierwsi w całej Ameryce jako parafjanie przed wojną zbieraliśmy fundusz na oswobodzenie Ojczyzny i zebraliśmy do rozpoczęcia wojny do r. 1914, $\$ 7,260.96$.

2. My pierwsi założyliśmy w Ameryce Komitet Obywatelski przed wojną, a w czasie wojny wzięto z nas wzór.

3. My nie braliśmy za pracę ani jednego centa aż do dnia dzisiejszego, - inni brali i pobogacili się.

4. My pierwsi w Ameryce utworzyliśmy fundusz polskich inwalidów dnia 29-go listopada 1917 r. - za co nas skarżyli lewicowcy do Washingtonu, my mieli wpływ w Washingtonie i sprawę wygraliśmy, i nam pozwolono utworzyć. (Obecnie jeszcze mamy z $\$ 6,725.00$ na inwalidów w New Britain).

5. My pierwsi w Ameryce, jak powróciły pierwsze oddziały z armji polskiej i amerykańskiej, utworzyliśmy miejscowe wojskowe towarzystwa weteranów, które później zbuntowano nam i przychylono na stronę lewicy.

6. My jako parafja, najwięcej daliśmy ofiar, żadna parafja tyle nie dała, choć w New Britain nie mamy bogaczy jak gdzie indziej - niektórzy doszli do majątku pod koniec wojny i po wojnie, ale ci też mało dali. 
7. W całej Ameryce jeden tylko Ks. z New Britain był oficerem rekrutacyjnym. Sejm Polski w Warszawie nam uchwalił Polonia Restituta, ale ponieważ trzepaliśmy porządnie socjałów i niemców - pan prezydent Wojciechowski odmówił podpisu i zatwierdzenia - dzięki mu - boby lewica znów na nas napadłaby. Na zakończenie, jako były oficer rekrutacyjny, z prawa wojskowego mam prawo przedstawić Sz. Pana Antoniego Gorzkę do odznaczenia wojennego. Ten człowiek dziś nad grobem, ale był moim sierżantem rekrutacyjnym, pracował w dzień i w nocy do godziny 1 i 2-giej - wykonał wszystkie moje rozkazy znakomicie, nie patrząc jaka pogoda i gdzie go wysłano - wszędzie postąpił roztropnie - za pracę nie wziął ani centa - niech mu osłodzi krzyż jego pracę i poświęcenie, gdy dziś już nie może pracować i jest nad grobem.

Posyłam parę wycinków z gazety z ostatnich zajść, oraz odezwę dawniejszą w angielskim języku, gdzie burmistrz miasta wraz z śmietanką polską New Britańską popierał partję lewicową przeciw nam - za co dostali wszyscy po nosie.

Na zakończenie Witam i żegnam sz. p. Generała J. Hallera, pracuj jak pracowałeś, a historja będzie sprawiedliwszą nawet od niektórych tych, którzy cię dziś przyjmują, a przed tem utopiliby cię w łyżce wody. Prawda i praca zwycięża wszystko na świecie - już zwyciężasz, ale potem zatryumfujesz, czego ci życzy sz. p. Generale, były oficer rekrutacyjny.

Ks. L. Bójnowski ${ }^{42}$.

Parafie i Polska Rada Narodowa gotowe były również do wspólnego wysiłku z KON i delegatami w sprawie obrony dobrego imienia Polaków, atakowanych za skrajny antysemityzm przez znaczną część prasy amerykańskiej ${ }^{43}$. Parafie gościnnie przyjmowały R. Dmowskiego i innych polskich gości. Polonia śledziła jego rozmowy z prezydentem Wilsonem oraz przywódcami Żydów amerykańskich, którzy oczekiwali przyjęcia przez nowe państwo polskie specjalnych międzynarodowych zobowiązań dotyczących ochrony mniejszości narodowych. Przywódcy ludności żydowskiej w Stanach bali się wpływów obozu narodowego wśród Polonii i większości duchowieństwa, bali się także wizji odrodzonej Rzeczypospolitej jako państwa narodowego Polaków ${ }^{44}$. Niemniej, prasa polonijnokatolicka popularyzowała apele Paderewskiego o pomoc dla kraju, ceniąc jego bezpartyjność i sympatie dla Stolicy Apostolskiej (przyjaźń z Benedyktem XV).

${ }^{42}$ Cyt. za: L. Bójnowski, Historja parafji polskich $w$ diecezji hartfordskiejw stanie Connecticut, New Britain, Conn 1939, s. 168-175; Zob. R. Nir, Szkice z dziejów Polonii, Orchard Lake, Michigan 1990, s. 332-336.

${ }^{43}$ M.M. Drozdowski, Działalność Polonii amerykańskiej w walce zbrojnej o niepodległość Polski w latach 1910-1918, w: Polonia wobec niepodległości Polski w czasie I wojny światowej, red. H. Florkowska-Franćić, M. Franćić, H. Kubiak, Wrocław 1979, s. 69; Radzik, Polonia amerykańska wobec Polski, s. 126.

${ }^{44}$ Drozdowski, Stosunki polsko-amerykańskie w latach 1917-1919, s. 19; A. Kapiszewski, Stosunki polsko-żydowskie w Stanach Zjednoczonych Ameryki, w: Polonia amerykańska. Przeszłość $i$ wspótczesność, red. H. Kubiak, E. Kusielewicz, T. Gromada, Wrocław 1988, s. 617-625. 
Bp P. Rhode sam nie wahał się jeździć po kraju (USA), aby budzić zapał i organizować komitety lokalne ${ }^{45}$.

Wszystkie parafie chicagowskie spotkały się pod pomnikiem Tadeusza Kościuszki w Chicago na wielkim wiecu 3 maja 1915 r., gdzie m.in. rektor Kolegium św. Stanisława Kostki w Chicago ks. Zapała, ofiarny współpracownik Paderewskiego apelował do zebranych rodaków o pomoc. Na apel Paderewskiego większość parafii potraktowała dzień 15 lipca 1915 r. - rocznicę bitwy pod Grunwaldem jako Dzień Pracy dla Polski, wzbogacając fundusz Polskiego Centralnego Komitetu Ratunkowego o 80.000 dolarów $^{46}$. Zbiegło się to z podobnym apelem Benedykta XV do biskupów świata. Paderewski przypomniał wówczas publicznie wkład księży do polskiej nauki i sztuki, polemizując z antyklerykalnymi tonami publikacji KON. Na 600 polskich parafii katolickich funkcjonujących wówczas w USA, początkowo tylko w 150 utworzono lokalne komitety PRN ${ }^{47}$.

Wielkim osiągnięciem Paderewskiego i popierających go parafii była ogłoszona przez prezydenta Wilsona proklamacja 1 stycznia $1916 \mathrm{r}$. dniem zbiórki funduszy na pomoc dla ofiar wojny w Polsce. Wyniki zbiórki, w związku z rezerwą społeczeństwa amerykańskiego ukierunkowanego antypolsko przez część prasy, wypadły skromnie ${ }^{48}$. W marcu 1916 r. po recitalu fortepianowym dla korpusu dyplomatycznego doszło do pierwszego spotkania Paderewskiego z prezydentem T.W. Wilsonem. W czasie drugiego spotkania 6 października 1916 r. prezydent deklarował wobec Paderewskiego poparcie Stanów Zjednoczonych, wobec aspiracji niepodległościowych narodu polskiego. Po tej rozmowie, na prośbę Paderewskiego i powstałego Wydziału Narodowego Polskiego Centralnego Komitetu Ratunkowego, parafie polskie i organizacje ubezpieczeniowe brały udział w proteście przeciw rozporządzeniom państw centralnych w sprawie przyszłości państwa polskiego ${ }^{49}$.

${ }^{45}$ Haiman, Zjednoczenie Polskie-Rzymsko Katolickie w Ameryce, s. 281.

${ }^{46}$ Tamże, s. 281-282; Drozdowski, Z dziejów stosunków polsko-amerykańskich, s. 89, 91.

${ }^{47}$ Drozdowski, Z dziejów stosunków polsko-amerykańskich, s. 91.

48 Tamże, s. 92.

${ }^{49}$ Haiman, Zjednoczenie Polskie-Rzymsko Katolickie w Ameryce, s. 295-296; Drozdowski, Z dziejów stosunków polsko-amerykańskich, s. 93. 
Jednocześnie duchowieństwo, parafie polskie i organizacje zrzeszające naszych rodaków zorganizowały zbiórkę środków ${ }^{50}$ na rzecz wsparcia działań zainicjowanych przez Paderewskiego ${ }^{51}$.

${ }^{50}$ Wykaz ofiarodawców polskich do Komitetu Paderewskiego, „Dziennik Związkowy” - Zgoda, 11 maja 1917, s. 5. Następujące komitety i parafie złożyły datki od początku istnienia tego komitetu aż do 31-go grudnia 1916 roku: Związek Polek, Chicago - \$1.525.90; Unia Polska. Wilkes-Barre - 8,000.00; Polski Fundusz Ratunkowy, Luzerne County, Pa - 20,832.45; Klub Polskich Pań i Fundusz Narodowy z New Jersey - 1,600.00; Polski Bazar Jersey City - 2,777.25; Polski Fundusz Narodowy, New Jersey - 2,000.00; Polacy z Brooklyna za pośrednictwem Dr. Drobińskiego i innych - 1,850.00; Polski Centralny Komitet Ratunkowy w Philadelphi - 5,000.00; Polskie Towarzystwo Samokształcenia 1,025.00; Polacy w Milwaukee, p. Błeński i Gruta - 1,200.00; Polacy z New Jersey, przedstawienie Halki itd. - 2,000.00; Komitet Ratunkowy Bridgeport. Conn. - 1,194.00 Polski Komitet Ratunkowy Utica - 1,001.00; Polski Koncert w Brooklynie - 1,301,10; Polski Koncert w Detroit, państwo Electra i Leon Rosiccy - 766.00; Polski Bank. Chicago - 1,000.00; Polski Klub Handlowy, Toledo - 502.75; Polski Komitet Ratunkowy, Union Township, Bergen Co., N.J. - 646.50; Dzień Polski, Bronx - 660.47; Polski Komitet Ratunkowy, Ware, pan Bugiel - 636.04; Polski Koncert, Gary Ind. - 473.00; Polski Ratunkowy Komitet, Riverhead - 200.00; Polski Komitet Ratunkowy, Ragowski. Hartford - 360.00; Polska Rada Narodowa, Broooklyn - 300.00; Polska Rada Narodowa, Schenectady - 600.00; Polski Centralny Komitet Katolickich Parafii w St. Louis - 500.00; Połączone Towarzystwa Sp. w Brooklynie - 250.00; Polskie Towarzystwo Pułaskiego - 175.00; Aleksander Krzyżański - 300.00; Dr. Porembski, Youngstown - 262.50; Polskie Stowarzyszenie Dobroczynne, I. O. Pietruszko - 226.00; Polacy w New Yorku, Ks. Strzelecki - 1,000.00; Polacy w Passaic, Ks. Manteufel - 1,000.00; Polacy z Cambridge, Mass., Ks. Żmijewski - 2,065.00; Ks. Żmijewski - 80.00; Polskie Dzieci ze Szkoły Św. Stanisława, Ks. Strzelecki - 500.00; Polscy księża z New Yorku - 500.00; Różni Polscy księża - 400.00; Polscy księża z Toledo - 500.00; Polski Kościół Św. Wojciecha w Toledo - 414.00; Polski Kościół Św. Wojciecha w New Yorku - 220.00; Polski Kościół Serca Jezusa, Syracuse - 636.00; Polski Kościół Św. Jana Kantego, Brooklyn - 250.00; Polski Kościół Św. Jadwigi, Union City, Conn. - 200.00; Kościół Św. Franciszka, Omaha - 634.47; Ks. Malinowski - 116.41; Ks. A. J. Majewski - 100.00; Ks. Pudłowski - 214.25; Ks. Zieliński - 320.51; Ks. Jasionowski - 170.25; Ks. Luicki - 100.00; Ks. Sarnecki - 634.50; Ks. Czubek - 135.50; Ks. Syski - 112.25; Ks. Manteufel - 100.00; Ks. Wilamowski - 945.00; Ks. S. Kruczek - 646.50; Ks. S. Kruczek - 161.77; Ks. Adalber Duczmal - 624.00; Ks. Kulawy 365.81; Ks. Chlapowski - 150.00; Ks. Zdebel - 130.00; Ks. Kazimierz Ćwikliński - 300.00; Ks. Ryziakiewicz - 331.35; Ks. Rusin - 635.00; Ks. Wysiecki - 224.35; Ks. L. Bójnowski-1,500.00; Ks. Nawrocki, Chicago - 500.00; Ks. Cyran, Webster, Mass. - 500.00; Ks. Cyman, Chicopee - 500.00; Ks. Mazurkiewicz, Polski Komitet Ratunkowy, New Haven - 3,788.35; Ks. Mazurkiewicz, Polski Komitet Ratunkowy, New Haven - 1,217.96; Ks. Maciejewski - 1,030.00; Ks. S. Musiel - 850.00; Ks. P. Waszko - 250.00; Ks. Ceppa - 500.00; Ks. Żychowicz, Polski Komitet Ratunkowy, Scranton, $\mathrm{Pa}-2,220.37$; Ks. F. Wawer - 100.00; Ks. Zimmermann, Weterbury - 100.00; Ks. Piechowski - 309.00; Ks. Figlewski - 277.66; Ks. Mańka - 100.00; Ks. Kruszka - 100.00; Ks. Wiśniewski - 100.00; Ks. Żebrowski i L. Pajowski - 600.00; Ks. Matuszewski, South Bethlehem - 100.00; Razem - \$98, 712.22.

${ }^{51}$ Z chwili, „Dziennik Związkowy” - Zgoda 1 grudnia 1917, s. 4. Jak głosi ostatni komunikat Polskiego Funduszu Ratunkowego [...] w tygodniu kończącym się 23 listopada wpłynęło na rzecz głodnych w Polsce do kasy powyższej tylko instytucji \$ 8,000 i 81 centów. Z tego Polacy złożyli \$ 6.733.13, resztę Amerykanie. Polska ofiarność powyższego tygodnia przedstawia się następująco: Parafia polska w Bayonne, N.J. S 1274.25 ks. Józef Pokorny z Bayonne N.J \$ 50 Pol. Kom. Rat. w Philadelphia \$3000, ten sam Komitet druga przesyłka \$2000, prof. Zwierzchowski z Ann Arbor 
Istotnym wydarzeniem dla wszystkich parafii polskich było orędzie prezydenta Wilsona do Senatu z 22 stycznia 1917 r., w którym stwierdził, że „powinna powstać zjednoczona, niepodległa oraz samodzielna Polska" ${ }^{2}$. Po tym orędziu $\mathrm{z}$ apelem do całej Polonii, także do zwolenników KON, zwracał się Paderewski na Sejmie Związku Sokolstwa Polskiego 4 kwietnia 1917 r. przedstawiając idee utworzenia stutysięcznej Armii im. T. Kościuszki jako armii sojuszniczej Stanów Zjednoczonych ${ }^{53}$. Zarówno prezydent, jak też jego gabinet idee tę odrzucili. Odzew ze strony parafii polskich był zróżnicowany. Bardziej zasymilowane rodziny polskie bały się wysyłać swoich synów do Armii Polskiej o nieznanym statusie, wolały wysłać ich do armii amerykańskiej, co gwarantowało wszystkim otrzymanie obywatelstwa amerykańskiego i zabezpieczenie socjalne oraz pomoc państwa w kształceniu po odbyciu służby wojskowej ${ }^{54}$. W trzymilionowej armii amerykańskiej znalazło się wówczas ok. 200.000 Polaków, w znacznej części już zasymilowanych ${ }^{55}$.

Od 1 lipca 1917 r. Paderewski legitymował się formalnym pełnomocnictwem do reprezentowania wobec władz Stanów Zjednoczonych organizacji skupiających ok. 500.000 członków zgrupowanych wokół liczącego się w strukturze Polonii Wydziału Narodowego ${ }^{56}$. Po utworzeniu Armii Polskiej we Francji, Paderewski po konsultacjach z R. Dmowskim przekonał Wydział Narodowy i najbardziej patriotyczne parafie o konieczności zorganizowania rekrutacji polonijnych ochotników do Armii Polskiej we Francji. Paderewski uzyskał uznanie przez rząd amerykański Komitetu Narodowego Polskiego i zgodę na rekrutację polskich ochotników, nie posiadających obywatelstwa amerykańskiego ${ }^{57}$. Akcje rekrutacji Wydział Narodowy rozpoczął od 7 października 1917 r. Parafie polskie gościnnie przyjmowały polską misję wojskową. W wielu parafiach odczytano w tej sprawie odezwę Wydziału Narodowego, zredagowaną przez Paderewskiego:

Idźcie, by świat przekonać, że Polak amerykański orężnej polskiej chwały godnym jest spadkobiercą. Bez Gopła, Kruszwicy, Gniezna, Poznania, sędziwej Narodu kolebki nie może być Polski (...) Bez śląskich prastarych siedzib

Mich. \$ 131,05, Michał Dziób z Woonsocket R.I. \$ 111,83, Jan Moszczeński z Brooklyna \$ 70, ks. Chodkiewicz z Bayoona \$25, Tomasz Łagoda z Bayoone \$ 20 i Krzywa I Klebań z Bayoone po $-10 "$ ".

${ }^{52}$ Piekoszowski, Problemy Polonii amerykańskiej, s. 165; Drozdowski, Z dziejów stosunków polsko-amerykańskich, s. 96; Haiman, Zjednoczenie Polskie-Rzymsko Katolickie w Ameryce, s. 297.

${ }^{53}$ Drozdowski, Z dziejów stosunków polsko-amerykańskich, s. 114.

${ }^{54}$ Tenże, Stosunki polsko-amerykańskie w latach 1917-1919, s. 10.

${ }^{55}$ Radzik, Polonia amerykańska wobec Polski, s. 386.

${ }^{56}$ Brożek, Próby zjednoczenia Polonii amerykańskiej, s. 158; Drozdowski, Stosunki polsko-amerykańskie w latach 1917-1919, s. 12; tenże, Z dziejów stosunków polsko-amerykańskich, s. 116; M. Zgórniak, Polonia amerykańska wobec problemu niepodległości w czasie I wojny światowej, w: Polonia amerykańska. Przeszłość i wspótczesność, red. H. Kubiak, E. Kusielewicz, T. Gromada, Wrocław 1988, s. 737.

${ }^{57}$ Drozdowski, Stosunki polsko-amerykańskie w latach 1917-1919, s. 15; tenże, Z dziejów stosunków polsko-amerykańskich, s. 123. 
piastowskich nie może być Polski (...) Bez ujścia Wisły, morskiego wybrzeża, bez odwiecznego Gdańska naszego, nie może być Polski ${ }^{58}$.

We wszystkich parafiach polskich w Stanach dla propagandy akcji rekrutacyjnej wykorzystano setną rocznicę śmierci Tadeusza Kościuszki ${ }^{59}$. Polskie parafie - jak zauważył A. Walaszek - stały się wówczas podstawą akcji rekrutacyjnej do Armii Polskiej ${ }^{60}$. Już w listopadzie 1917 r. gotowość do wstąpienia do Armii Polskiej we Francji zgłosiło 35.395 osób. W czasie I wojny światowej Polonia w New Britain złożyła na cele polskie $182.911,84$ dolarów, zaś do armii polskiej wstąpiło 290 rodaków $^{61}$. Polonia amerykańska dostarczyła do Armii Polskiej we Francji więcej ochotników, aniżeli wynosił stan osobowy Legionów J. Piłsudskiego ${ }^{62}$.

Prezydent Wilson ulegajac coraz większej presji Polonii z jej Polskim Wydziałem Narodowym na miejscu i Polskim Komitetem Narodowym w Paryżu, 8 stycznia 1918 r. ${ }^{63}$ sformułował czternastopunktową rezolucję, w której trzynasty punkt programu pokojowego poświęcił całkowicie Polsce, stwierdzając, iż: „ma być utworzone niepodległe państwo polskie z wolnym dostępem do morza" ${ }^{4}$. Przez parafie polskie i Wydział Narodowy program ten został przyjęty z umiarkowanym optymizmem, oczekiwano bowiem jednoznacznego stanowiska prezydenta w sprawie prawa Polski do Pomorza, Warmii, Mazur, Wielkopolski, Śląska i Kresów Wschodnich, a tego w programie pokojowym prezydenta nie było.

Z kręgów księży polonijnych, dla zaktywizowania działań Polonii na rzecz niepodległości Polski, wyszła inicjatywa zorganizowania Kongresu Polskiego w Stanach Zjednoczonych. W dniu 13 lutego 1918 r. ks. Lucjan Bójnowski charakteryzując przeciętnego rodaka mieszkającego za oceanem pisał do Paderewskiego:

Nasz przeciętny wychodźca w najlepszym razie był i jest etnograficznym tylko materiałem i oprócz wspomnień rozczochranych opłotków swej wsi (tak rażąco odbijających od amerykańskiego dobrobytu i wygód) pusto w jego głowie i jego sercu pod względem tego wszystkiego, co nazywamy polskością, Ojczyzną. Zatem jeśli da się on przyciągnąc do polskich interesów, to chyba jedynie prośbą lub jakimś osobistym zyskiem. Młode, podrosłe tu pokolenie odznacza się wielką dozą dwulicowego wyrachowania ${ }^{65}$.

\footnotetext{
${ }^{58}$ Cyt. za: Radzik, Polonia amerykańska wobec Polski, s. 20.

${ }^{59}$ Zgórniak, Rola Polonii w walce zbrojnej o niepodległość Polski, s. 43.

${ }^{60}$ Walaszek, Kościót, etniczność, demokratyzacja-parafie polonijne w USA, s. 64.

${ }^{61}$ Ks. B. Kumor, Z problemów ludnościowych polskiej parafii Najśw. Serca Jezusowego w New Britan, Conn. (1895-1920), „Studia Polonijne”, 5 (1982) s. 262; Por. przypis. 42.

${ }^{62}$ Brożek, Próby zjednoczenia Polonii amerykańskiej, s. 158; Zgórniak, Rola Polonii w walce zbrojnej o niepodległość Polski, s. 43. Do 26 III 1919 r. wysłano do Francji 20720 polskich rekrutów.

${ }^{63}$ Szulist, Kaszuba Pawet Piotr Rhode - biskup i działacz polonijny w Stanach Zjednoczonych,

${ }^{64}$ Piekoszowski, Problemy Polonii amerykańskiej, s. 165; Drozdowski, Z dziejów stosunków polsko-amerykańskich, s. 120.

${ }^{65}$ Radzik, Polonia amerykańska wobec Polski, s. 380-381.
} s. 189. 
Jest dyskusyjne, jaki procent imigrantów np. z zaboru pruskiego miał skrystalizowaną świadomość narodową.

Jozef Bartula z Bremond w Teksasie zarzucał w roku 1879 miejscowym Poznaniakom, że uważają się za Prusaków. W 1906 r. organ ZNP „Zgoda” stwierdzał, że Kaszubi są tak samo dobrymi Polakami jak inni. Wiosną 1914 r. Tomasz Ziętkowski z Detroit mówił o wielu imigrantach spod panowania niemieckiego i z Galicji, zaliczających się do Niemców, jeśli wyraźnie nie każe im się zapisywać jako Polakom. Apele o deklarowanie polskości pojawiały się w prasie polonijnej niemal przed każdym spisem. Zaś upowszechniony pogląd o wyższym poziomie wykształcenia i świadomości przybyszów z zaboru pruskiego spotykał się niekiedy z zastrzeżeniami emigrantów galicyjskich ${ }^{66}$.

Trzeba przyznać, że pod wpływem duszpasterzy polskich - jak argumentował ks. Jan Piekoszewski - amerykański Polak stawał się coraz bardziej dumny ze swojej polskości. Ten, który miał tak niewielkie powiązania z krajem ojczystym, którego świadomość narodowa była prawie żadna, a poczucie łączności z całością narodu, jego przeszłością, instytucjami i kulturą równe niemal zeru, ten właśnie emigrant zaczął przejawiać szersze zainteresowanie Starym Krajem ${ }^{67}$.

W dniu 22 maja 1918 r. Wydział Narodowy podjął decyzję o powołaniu w Stanach Zjednoczonych Polskiego Białego Krzyża pod kierownictwem Heleny Paderewskiej ${ }^{68}$. I tym razem, zgodnie $z$ apelem poprzez parafie została zorganizowana akcja zbiórki darów na rzecz Armii Polskiej we Francji i rekrutacji kandydatek na sanitariuszki. Postanowiono także zwołać Kongres Wychodźstwa Polskiego. Wśród jego organizatorów było Zjednoczenie Kapłanów Polskich. Natomiast patronat nad Polskim Białym Krzyżem na prośbę Paderewskiego objął bp P. Rhode.

Duchowni byli bardzo aktywni podczas Sejmu Polskiego w Detroit, który rozpoczął swe obrady 26 sierpnia 1918 r. Podzielali oni pogląd Paderewskiego o licznych porażkach politycznych Polonii amerykańskiej w postaci: odrzucenia przez rząd amerykański idei Armii Polskiej w Stanach Zjednoczonych, braku deklaracji obu izb Kongresu w sprawie uznania niepodległości Polski, trudności Departamentu Sprawiedliwości przy wydawaniu świadectw o narodowości polskiej i braku pomocy dla Armii Polskiej w Rosji, nikłej ofiarności Polonii na potrzeby kraju. Sejm przyjął uchwałę w sprawie opodatkowania Polonii do wysokości 10 mil. dol. na potrzeby kraju ${ }^{69}$. Nad przebiegiem akcji zbiórkowej czuwać miały specjalne komisje poboru powołane w każdej parafii i osadzie, bez względu na różnice wyznaniowe i światopoglądowe. W rzeczywistości - jak przyznał T. Radzik - komisje działały głównie w oparciu o parafie oraz komitety obywatelskie. $\mathrm{W}$ praktyce, podatek narodowy zbierali proboszczowie w parafiach polskich. W miejscowościach, w których nie było parafii polskich bądź proboszcz nie godził się na zbiórkę, zadania te przejmowały miejscowe komitety obywatelskie,

\footnotetext{
${ }^{66}$ Groniowski, Emigranci z zaboru pruskiego, s. 319.

${ }^{67}$ Piekoszowski, Problemy Polonii amerykańskiej, s. 165.

${ }^{68}$ Drozdowski, Stosunki polsko-amerykańskie w latach 1917-1919, s. 20; Radzik, Spoteczno-ekonomiczne aspekty stosunku Polonii amerykańskiej, s. 13.

${ }^{69}$ Drozdowski, Z dziejów stosunków polsko-amerykańskich, s. 129-130.
} 
działające w imieniu Wydziału Narodowego ${ }^{70}$. Na początku listopada o poparcie zbiórki zwrócił się w liście do Polonii i duchowieństwa polskiego w swojej diecezji bp P. Rhode. Udzielając swojego poparcia stwierdził m.in., że „Nie wart miana Polaka ten, który rzetelnie nie wspiera starań Braci naszych za oceanem"71. Nie ulega więc wątpliwości, że zebrane środki na pomoc rodakom na ziemiach polskich zawdzięczamy „księżom i ich autorytetowi w parafii oraz pewnej presji, jaka się wobec ich postawy wytwarzała w lokalnej społeczności parafialnej"72. Proboszczowie parafii polskich, czasem lokalne grupy Zjednoczenia Kapłanów Polskich, w odpowiedzi na prośby duszpasterzy z kraju kierowane do dawnych parafian mieszkających w Ameryce udzielały bezpośredniego indywidualnego wsparcia wspólnotom parafialnym na ziemiach polskich ${ }^{73}$.

Polonia katolicka na czele z bp. P. Rhode zintensyfikowała dostawy żywności do umęczonego kraju, z żalem też żegnała I. Paderewskiego 22 listopada 1918 r. udającego się z misją utworzenia rządu koalicyjnego w Polsce ${ }^{74}$. Po odjeździe Paderewskiego faktycznym przywódcą Polonii został Jan Smulski, prezes Wydziału Narodowego Polskiego, ideowo związany z R. Dmowskim ${ }^{75}$. Na jego apel i tym razem parafie zorganizowały nową zbiórkę pieniędzy, żywności, odzieży i lekarstw dla kraju. Służyć ona miała wzmocnieniu aktywów gabinetu Paderewskiego uformowanego 16 stycznia $1919 \mathrm{r}$.

Polacy amerykańscy bez względu na przekonania, starali się osiągnąć swoje cele poprzez rozwijanie aktywności na wielu płaszczyznach, usiłując również wpłynąć na prezydenta Thomasa W. Wilsona. Szczególnie skuteczne okazały się wysiłki podjęte przez Ignacego Jana Paderewskiego i Komitet Narodowy Polski $\mathrm{z}$ siedzibą w Paryżu ${ }^{76}$. Najczęściej wszystkie te działania podejmowano w oparciu o duchowieństwo i polskie wspólnoty parafialne, które z jednej strony zapoznawały parafian z kulturą i życiem amerykańskim, a z drugiej szerzyły wiedzę $\mathrm{z}$ zakresu historii i kultury polskiej. Funkcjonujące $\mathrm{w}$ ich ramach organizacje i towarzystwa tak o charakterze religijnym jak i pozareligijnym dawały osobom identyfikujących się z nimi poczucie bezpieczeństwa i akceptacji. Pomimo tak znaczącego zaangażowania społeczności polonijnej w USA, nie udało się jednak doprowadzić do jedności działania Wydziału Narodowego i Komitetu Obrony Narodowej, co niewątpliwie osłabiło wysiłki Polonii amerykańskiej na rzecz niepodległości.

\footnotetext{
${ }^{70}$ Radzik, Społeczno-ekonomiczne aspekty stosunku Polonii amerykańskiej, s. 27.

${ }^{71}$ List J.E. Biskupa P. Rhodego Do Wielebnego Duchowieństwa Polskiego i do ogółu Braci Polaków w diecezji Green Bayskiej, „Dziennik Chicagoski”, 8 listopada 1918, s. 7.

${ }^{72}$ Radzik, Społeczno-ekonomiczne aspekty stosunku Polonii amerykańskiej, s. 30.

${ }^{73}$ Z naszych grup. Z rocznego posiedzenia zarzadu i dyrektoriatu Zjednoczenia Kapłanów Polskich w Ameryce. Sprawozdanie, „Przegląd Kościelny”, 11 (1919) s. 781.

${ }^{74}$ Haiman, Zjednoczenie Polskie-Rzymsko Katolickie w Ameryce, s. 316; Drozdowski, Działalność Polonii amerykańskiej w walce zbrojnej o niepodległość Polski, s. 69.

${ }^{75}$ Groniowski, Emigranci z zaboru pruskiego, s. 319.

${ }^{76}$ Brożek, Próby zjednoczenia Polonii amerykańskiej, s. 157.
} 


\section{BIBLIOGRAFIA}

Baker T.L., Wczesna historia osady Panna Maria w Teksasie, „Przegląd Polonijny”, 4 (1978) z. 2(8), s. 41-49.

Borys M., Rola polskich parafii rzymskokatolickich $w$ życiu Polonii chicagowskiej $w$ XIX wieku, „Studia Polonijne” 30 (2009), s. 151-170.

Bójnowski L., Historja parafji polskich $w$ diecezji hartfordskiej w stanie Connecticut, New Britain, Conn 1939.

Brożek A., Polonia amerykańska 1854-1939, Warszawa 1977.

Brożek A., Próby zjednoczenia Polonii amerykańskiej i ich ideologie, w: Polonia amerykańska. Przeszłość i teraźniejszość, red. H. Kubiak, E. Kusielewicz i T. Gromada, Wrocław-Warszawa 1988, s. 149-176.

Czerwińska M., Inkulturacyjna rola parafii polonijnej w USA na przykładzie wybranych parafii polonijnych z Chicago, Detroit i Nowego Jorku (1867-1976), „Studia Polonijne", 28 (2007) s. 243-270.

Drozdowski M.M., Działalność Polonii amerykańskiej $w$ walce zbrojnej o niepodległość Polski w latach 1910-1918, w: Polonia wobec niepodległości Polski w czasie I wojny światowej, red. H. Florkowska-Franćić, M. Franćić, H. Kubiak, Wrocław 1979, s. 6387.

Drozdowski M.M., Stosunki polsko-amerykańskie w latach 1917-1919w świetle Archiwum Politycznego Ignacego Paderewskiego, „Przegląd Polonijny”, 3 (1977) z. 1 (5), s. 5-21.

Drozdowski M.M., Z dziejów stosunków polsko-amerykańskich 1776-1944, Warszawa 1982.

Filipowicz S., Saga polskich Jezuitów w USA, Kraków 2004.

Galush W., Polacy amerykańscy i nowa Polska. Przykłady przemiany orientacji etnicznej, „Przegląd Polonijny”, 6 (1980) z. 3(17), s. 86-103.

Gogola Z., Praca franciszkanów polskich wśród Polonii na przełomie XIX/XX, do 1939 roku, „Przeglad Kalwaryjski”, 13 (2009) s. 189-223.

Groniowski K., Emigranci z zaboru pruskiego w Stanach Zjednoczonych, „Komunikaty Mazursko-Warmińskie", 3-4 (1988), s. 311-320.

Haiman M., Zjednoczenie Polskie-Rzymsko Katolickie w Ameryce 1873-1948, Chicago 1948.

Historia polskich rzymsko-katolickich parafij archidiecezji filadelfijskiej w Stanach Zjednoczonych Pótnocnej Ameryki, Philadelphiae 1938.

Kapiszewski A., Stosunki polsko-żydowskie w Stanach Zjednoczonych Ameryki, w: Polonia amerykańska. Przeszłość i współczesność, red. H. Kubiak, E. Kusielewicz i T. Gromada, Wrocław 1988, s. 609-671.

Kiper D., Przyjaciel Ludu” wobec prób zjednoczenia Polonii amerykańskiej w latach 1880-1881, „Studia Polonijne”, 33 (2012) s. 79-90.

Kruszka W., Historya polska w Ameryce. Początek, wzrost i rozwój dziejowy osad polskich w Pólnocnej Ameryce (w Stanach Zjednoczonych i Kanadzie), t. 13, Milwaukee, Wis, 1908.

Kubiak H., Położenie społeczne i ewolucja świadomości narodowej ludności polskiej w USA w latach 1900-1919, w: Polonia wobec niepodległości Polski w czasie I wojny światowej, red. H. Florkowska-Franćić, M. Franćić, H. Kubiak, Wrocław 1979, s. $49-62$.

Kumor B., Z problemów ludnościowych polskiej parafii Najśw. Serca Jezusowego w New Britan, Conn. (1895-1920), „Studia Polonijne”, 5 (1982) s. 261-278. 
Leś B., Kościót w procesie asymilacji Polonii amerykańskiej. Przemiany funkcji polonijnych instytucji i organizacji religijnych $w$ środowisku Polonii chicagowskiej, Wrocław 1981.

List J.E. Biskupa P. Rhodego Do Wielebnego Duchowieństwa Polskiego i do ogółu Braci Polaków w diecezji Green Bayskiej, „Dziennik Chicagoski” 8 listopada 1918.

Micewski B., Polonijna działalność Zmartwychwstańców, w: Działalność męskich zgromadzeń zakonnych wśród Polonii, red. ks. J. Bakalarz i in., Lublin 1982, s. 403-452.

Nir R., Bibliografia selektywna Dziennika Chicagoskiego 1892-1895, 1898-1899, Select Bibliography Dziennik Chicagoski 1892-1895, 1898-1899, w: Yearbook Polish American Archives, Rocznik Archiwum Polonii, Vol. II, Orchard Lake, Michigan-Częstochowa 2004, s. 367-409.

Osada S., Jak się kształtowała polska dusza Wychodztwa w Ameryce, Pittsburgh, Pa. 1930.

Nir R., Polonijne czasopisma religijne, w: „Encyklopedia Katolicka”, t. 15, Lublin 2011, kol. 1138.

Nir R., Szkice z dziejów Polonii, Orchard Lake, Michigan 1990.

Piech S., Wkład księży diecezji tarnowskiej w duszpasterstwo Polonii zagranicznej (18731914), „Tarnowskie Studia Teologiczne”, 10 (1986) s. 116-132.

Piekoszowski J., Problemy Polonii amerykańskiej, Warszawa 1981.

Praszałowicz D., Rola żeńskich zakonów w życiu skupisk polonijnych w Stanach Zjednoczonych, w: Polska - Dwa Światy. Kraj i Polonia, red. W. Gliński, W. J. Wysocki, Warszawa 2009, s. 205-220.

Radzik T., Polonia amerykańska wobec Polski (1918-1939), Lublin 1986.

Radzik T., Społeczno-ekonomiczne aspekty stosunku Polonii amerykańskiej do Polski po I wojnie światowej, Wrocław 1989.

Stasik F., Polska emigracja polityczna w Stanach Zjednoczonych Ameryki 1831-1864, Warszawa 1973.

Szawleski M., Wychodźstwo polskie w Stanach Zjednoczonych Ameryki, Lwów 1924.

Szteinke A.J., Bracia Mniejsi na rzecz Polonii w Stanach Zjednoczonych Ameryki Pótnocnej w XIX i XX wieku, „Przeglad Kalwaryjski”, 13 (2009) s. 135-165.

Szulist W., Kaszuba Pawet Piotr Rhode - biskup i działacz polonijny w Stanach Zjednoczonych (1870-1945), „Studia Polonijne”, 8 (1984) s. 183-194.

Szymański J., Początki polskojęzycznej prasy katolickiej $w$ Stanach Zjednoczonych (do roku 1890), „Scripta Historica”, 22 (2016) s. 47-61.

Taras P., Problemy duszpasterstwa polonijnego na przykładzie USA, „Studia Polonijne”, 2 (1977) s. 181-205.

Walaszek A., Kościót, etniczność, demokratyzacja - parafie polonijne w USA (18541930), „Studia Migracyjne - Przegląd Polonijny”, 155 (2015) z. 1, s. 5-66.

Włoszczewski S., Polonia amerykańska. Szkice historyczne i socjologiczne, Warszawa 1971.

Wojewoda T., Problemy szkolnictwa polonijnego $w$ USA w świetle relacji ks. Józefa Rokosznego, „Studia Polonijne”, 21 (2000) s. 75-95.

Wykaz ofiarodawców polskich do Komitetu Paderewskiego, „Dziennik Związkowy” Zgoda, 11 maja 1917, s. 5.

Zahajkiewicz Sz., Księża i parafie polskie w Stanach Zjednoczonych Pót. Am., Chicago 1897.

Z chwili, „Dziennik Związkowy” - Zgoda 1 grudnia 1917, s. 4.

Zgórniak M., Polonia amerykańska wobec problemu niepodległości w czasie I wojny światowej, w: Polonia amerykańska. Przeszłość i współczesność, red. H. Kubiak, E. Kusielewicz i T. Gromada, Wrocław 1988, s. 727-744. 
Zgórniak M., Rola Polonii w walce zbrojnej o niepodległość Polski w latach 1914-1918, $\mathrm{w}$ : Polonia wobec niepodległości Polski w czasie I wojny światowej, red. H. Florkowska-Franćić, M. Franćić, H. Kubiak, Wrocław 1979, s. 29-48.

Z naszych grup. Z rocznego posiedzenia zarządu i dyrektoriatu Zjednoczenia Kapłanów Polskich w Ameryce. Sprawozdanie, „Przegląd Kościelny”, 11 (1919) s. 781.

Zwiercan A., Działalność Franciszkanów wśród Polonii, „Studia Polonijne”, 3 (1979) s. $87-202$.

\section{PARAFIE I DUCHOWIEŃSTWO POLSKIE W USA W WALCE O NIEPODLEGLOŚĆ POLSKI}

\section{Streszczenie}

Polskie parafie narodowościowe Kościoła rzymskokatolickiego w Stanach Zjednoczonych Północnej Ameryki były najważniejszą instytucją wychodźstwa polskiego w tym kraju. Największy ich rozwój nastąpił w czasie emigracji chłopskiej z ziem polskich (1870-1914). Pierwsza polska parafia powstała w 1854 r. w Pannie Marii w Teksasie. W 1870 r. parafii było ok. 10, w 1910 r. ponad 500. Ich wielkość wahała się od kilkunastu rodzin do kilkudziesięciu tysięcy wiernych. Na jednego duszpasterza w $1880 \mathrm{r}$. przypadało ok. 2.000 wiernych, w 1910 r. - ok. 4.000 .

Od 1870 r. wśród Polonii amerykańskiej ścierały się dwa kierunki starające się jednoczyć Polaków: Zjednoczenie Polskie Rzymsko Katolickie dążyło do zintegrowania działań społeczno-politycznych wokół ośrodków kościelnych (parafii, towarzystw katolickich), Związek Narodowy Polski robił to w oparciu o organizacje narodowe. Obydwa odłamy dążąc do zachowania integralności kulturowej rodaków, ze względu na cel nadrzędy - niepodległość Rzeczpospolitej - cieszyły się poparciem polskiego duchowieństwa.

W grudniu 1912 r. przywódcy polskich organizacji utworzyli Komitet Obrony Narodowej. W dniu 8 czerwca 1913 r. powołano Polską Radę Narodową, a 2 października 1914 r. - Rada Narodowa i Komitet Obrony Narodowej powołały Centralny Komitet Polski.

Po 1900 r. rozwinęły się w Polsce dwa zasadnicze nurty polityczne, z których każdy szukał poparcia wśród Polaków amerykańskich. Zarówno Roman Dmowski, jak i Józef Piłsudski zabiegali o ich wsparcie finansowe. W połowie 1913 r. Dmowski założył Komitet Narodowy Polski, który później przemianowany został na Wydział Narodowy Polski. Podobnie Polonia amerykańska ze względu na różnicę poglądów co do sprawy niepodległości Polski podzielona była na dwa zasadnicze odłamy. Wydział Narodowy podzielał pogląd Dmowskiego. Komitet Obrony Narodowej podzielał pogląd Piłsudskiego. Zwaśnionych od maja 1915 r. próbował godzić Ignacy Paderewski. Od 1 lipca 1917 r. legitymował się on formalnym pełnomocnictwem liczących się w strukturze Polonii organizacji do reprezentowania ich wobec władz Stanów Zjednoczonych.

Polacy amerykańscy, starali się osiągnąć swoje cele poprzez rozwijanie aktywności na wielu płaszczyznach, usiłując wpłynąć na prezydenta USA. Skuteczne okazały się wysiłki Ignacego Jana Paderewskiego i Komitetu Narodowego Polskiego z Paryża. Polskie parafie stały się podstawą akcji rekrutacyjnej do Armii Polskiej. W listopadzie $1917 \mathrm{r}$. gotowość do wstąpienia do Armii Polskiej we Francji zgłosiło 35.395 osób.

Prezydent Wilson ulegając presji Polonii, 8 stycznia 1918 r. sformułował czternastopunktową rezolucję, w której trzynasty punkt programu poświęcił Polsce, stwierdzając, iż: „ma być utworzone niepodległe państwo polskie z wolnym dostępem do morza”.

Słowa kluczowe: Polonia w USA; Parafie polskie w USA; duszpasterze polscy; walka o niepodległość; pierwsza wojna światowa 


\title{
PARISHES AND POLISH CLERGY IN THE USA FIGHTING FOR POLAND'S INDEPENDENCE
}

\begin{abstract}
Summary
Polish national parishes of the Roman Catholic Church in the United States of North America were the most important institutions in exile in this country. The greatest development occurred during farmers' emigration from Poland's land (1870-1914). The first Polish parish was created in 1854 in Panna Maria in Texas. In 1870 there were 10 such parishes, and in 1910 over 500. Each parish had from over a dozen families to several tens of thousands of the faithful. In 1880 there were around 2 thousand faithful to one priest, and in 1910 - around 4 thousand.

From 1870 onwards, there were two clashing trends attempting to unify American Poles: one (Polish Roman Catholic Union of America) strove to integrate social and political activity around church institutions (parishes, Catholic associations), the other one - Polish National Alliance, did it concentrating on national organizations. Both fractions trying to maintain the cultural integrity of Poles - the Republic of Poland's independence - were very popular with Polish clergy.

In December 1912, the leaders of the largest Polish organizations established the National Defense Committee. On 8 June 1913, the Polish National Council was created, 2 October 1914 - the National Council and the National Defense Committee appointed the Central Polish Committee.

After 1900 two political trends developed in Poland, and each of them sought support among American Poles. Both Roman Dmowski and Józef Piłsudski attempted to receive financial aid. In the mid-1913, Dmowski established the Polish National Committee, which was later transformed into the Polish National Department. Similarly, the Polish community in the USA, due to different attitudes to Poland's independence was divided into two fractions. The National Department shared Dmowski's views while the National Defense Committee shared Piłsudski's views. Ignacy Paderewski, who came to the United States in May 1915 tried to reconcile both parties. From 1 July 1917 onwards, he was formally authorized to represent the organization of the Polish community while talking to the authorities of the United States.

American Poles, irrespective of their views, tried to achieve their goals by being active in various fields and striving to influence President Thomas W. Wilson. All efforts made by Ignacy Paderewski and the Polish National Committee based in Paris proved to be effective. Polish parishes became the basis for the recruitment to the Polish Army. In November 1917, 35.395 people declared their readiness to join the army.

President Wilson gave in to the pressure of the Polish community, and on 8 January 1918 , he issued the fourteen-point resolution, in which the 13th point of the peace program devoted to Poland stated that: 'An independent Polish state should be erected (...)which should be assured a free and secure access to the sea.'
\end{abstract}

Keywords: the Polish community in the USA; Polish parishes in the USA; Polish priests; fighting for independence 